\title{
Correlation Between Eating Patterns and Nourish Status Among Medical Students of Sarajevo University
}

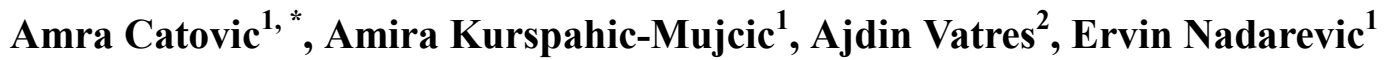 \\ ${ }^{1}$ Faculty of Medicine, University of Sarajevo, Sarajevo, Bosnia and Herzegovina \\ ${ }^{2}$ Faculty of Mechanical Engineering, University of Sarajevo, Sarajevo, Bosnia and Herzegovina
}

Email address:

amra.catovic@mf.unsa.ba (A. Catovic)

${ }^{*}$ Corresponding author

\section{To cite this article:}

Amra Catovic, Amira Kurspahic-Mujcic, Ajdin Vatres, Ervin Nadarevic. Correlation Between Eating Patterns and Nourish Status Among Medical Students of Sarajevo University. International Journal of Nutrition and Food Sciences. Vol. 7, No. 1, 2018, pp. 1-4. doi: 10.11648/j.jijnfs.20180701.11

Received: October 31, 2017; Accepted: November 15, 2017; Published: December 14, 2017

\begin{abstract}
University students experience numerous health-related behavioral changes, including the adoption of unhealthy dietary habits. This study aimed to assess the nourish status in a sample of students from Faculty of Medicine of Sarajevo University and correlate it with students eating habits. A cross-sectional survey of 68 students was performed during February and March 2016, at the Sarajevo University. Verbal informed consent was obtained from all participants before completing the self-administered questionnaire that included questions on their eating habits and anthropometrics measures, weight and height. Body mass index was used to assess students nourish status. Statistical analyses were performed using the Statistical Package for Social Sciences software (version 13.0). This study showed that the majority of the students $(69.12 \%)$ were of normal weight. Intakes of fruit and raw vegetables were more common among students with $B M I \leq 24.9 \mathrm{~kg} / \mathrm{m}^{2}$ than students with $\mathrm{BMI} \geq 25 \mathrm{~kg} / \mathrm{m}^{2}(\mathrm{P}=0.0004$ and $\mathrm{P}=0.046$ respectively). Consumption frequency of coca cola and beverages was less common $(\mathrm{P}=0.005)$ among students with $\mathrm{BMI} \leq 24.9 \mathrm{~kg} / \mathrm{m}^{2}$. This study gives baseline information about weight status and eating habits among a sample of university students. Regulating the energy density of food could be used as an approach for successful body weight control.
\end{abstract}

Keywords: Studying Youth, Lifestyle, Diet, Promotion Program

\section{Introduction}

Diet is a key determinant of human health and wellbeing. It is an essential factor of human physical and mental development. Deterioration of health, caused by inadequate nutrition, has epidemic proportion. There is relationship between health and food consumption, dietary patterns, nutrition and lifestyles. [1] Underestimate health consequences of lifestyle factors is compromised dental conditions. [2] Studying youth have great demands for energy necessary to cover mind activity associated with learning processes. Energy drink consumption has been linked with risk-seeking behaviors. [3]

Intercountry comparable overweight estimates from 2016 show that $56.4 \%$ of the adult population ( $>18$ years old) in Bosnia and Herzegovina were overweight. The prevalence of overweight was higher among men $(62.0 \%)$ than women $(51.2 \%)$. [4]

The food consumption patterns of young adults have been limited explored in Bosnia and Herzegovina. Exploring this health-related factor is necessary to implement a nutrition and health promotion program. This study aimed to assess the nourish status in a sample of students from Faculty of Medicine of Sarajevo University and correlate it with student eating habits.

\section{Methods}

\subsection{Design and Sample}

A cross-sectional study was conducted during February and March 2016 at Faculty of Medicine of Sarajevo University. A sample of 68 students $(27.94 \%$ male and 
$72.06 \%$ female), aged $26.01 \pm 2.72$ years participated in this study. As participants had to be informed about questionnaire random selection of university students was not possible, and the sample was limited to student who were interested in diet issues.

The study was conducted according to the research ethics guidelines laid down in the Declaration of Helsinki. [5] Verbal informed consent was obtained from all participants before completing the self-administered questionnaire.

\subsection{Data Collection}

Students were handed a self-administered anonymous questionnaire that included questions related to anthropometric and dietary information.

The FFQ used in this study was adapted from the CDC Global School Health Survey. [6] The finally used items in the FFQ were fruits, raw vegetables, cooked vegetables, coca cola and beverages, sweets (ice cream, chocolate,...), chips, fried potatoes, cake, fast food (hamburger, hotdog, sausages) bread and derivatives, milk, coffee, red meat, white meat, fish.

The FFQ asked how often each food item, group, or beverage was usually consumed with five possible answers for each of the food categories: (1) never, (2) two to three times per month, (3) two to three times per week, (4) at least one time per day, and (5) several times per day. These five response categories were later merged into two categories for analysis purposes, namely: (1) never and once or twice per month - rear, (2) two to three times per week, and (3) consumption on weekly basis - often.

Self-reported height and weight were used to calculate BMI $\left(\mathrm{kg} / \mathrm{m}^{2}\right)$. According to guidelines stated by the World Health Organization weight status was classified into four categories: under- weight (BMI $\leq 18.5)$, normal weight (BMI between 18.5 - 24.9), overweight (BMI between 25-29.9), and obese $(\mathrm{BMI} \geq 30)$.

\subsection{Data Analysis}

Statistical analyses were performed using the Statistical Package for Social Sciences (version 13.0, SPSS, Inc) software.

Results were expressed as means \pm SD (standard deviation). Parametric variables were analyzed using students' $t$-test, while Mann-Whitney test was used for nonparametric variables. To correlate nourish status and eating pattern chi-squared analyses were conducted. All reported $\mathrm{P}$ values were made on the basis of 2-sided tests; differences were considered statistically significant at $\mathrm{P}<0.05$.

\section{Results}

\subsection{Age Characteristics of the Students' Sample}

Mean age of a total of 68 students (19 males and 49 females) was $26.00 \pm 2.72$ years. Maximum was 34 years, and minimum was 23 years. There was no significant difference in age structure between gender (students' $t$-test: $\mathrm{P}=0.406$ ).

\subsection{Anthropometric Characteristics of the Students' Sample}

Anthropometric characteristics of the participated are presented by Table 1 . The average weight and height of all participated students was $68.82 \pm 14.77 \mathrm{~kg}$ and $173.49 \pm 9.06$ $\mathrm{cm}$, respectively. Mean BMI was $22.87 \pm 43.18 \mathrm{~kg} / \mathrm{m}^{2}$.

Table 1. Anthropometric characteristics of the participants (means $\pm S D$ ).

\begin{tabular}{llll}
\hline Variable & Total $(\mathbf{N}=\mathbf{6 8})$ & Males $(\mathbf{N}=19)$ & Females $(\mathbf{N}=\mathbf{4 9})$ \\
\hline Weight $(\mathrm{kg})$ & $68.82 \pm 14.77$ & $86.68 \pm 12.99$ & $63.29 \pm 9.23$ \\
Height $(\mathrm{cm})$ & $173.49 \pm 9.06$ & $183.95 \pm 7.90$ & $169.43 \pm 5.59$ \\
BMI $\left(\mathrm{kg} / \mathrm{m}^{2}\right)$ & $22.87 \pm 3.18$ & $25.12 \pm 3.02$ & $22.00 \pm 2.81$ \\
\hline
\end{tabular}

There were significant differences in weight, height and BMI between gender (students' $t$-test: $\mathrm{P}=0.0005$ for all three measures).

\subsection{Students' Nourish Status Based on BMI Categories}

It is showed by Table 2 that the majority of the students $(69.12 \%)$ were of normal weight $(36.84 \%$ of the male students compared to $81.63 \%$ of the female students). The prevalence of overweight was more common among male students compared to females $(63.16 \%$ vs. $14.29 \%)$.

Table 2. Prevalence of obesity among students based on BMI by gender.

\begin{tabular}{lllllll}
\hline \multirow{2}{*}{ Nourish status } & \multicolumn{2}{l}{ Males } & \multicolumn{3}{c}{ Females } & \multicolumn{2}{c}{ Total } \\
\cline { 2 - 7 } & $\mathbf{N}$ & $\mathbf{\%}$ & $\mathbf{N}$ & $\mathbf{\%}$ & $\mathbf{N}$ & $\mathbf{\%}$ \\
\hline Underweight* & - & - & 1 & 2.04 & 1 & 1.47 \\
Normal $*^{*}$ & 7 & 36.84 & 40 & 81.63 & 47 & 69.12 \\
Overweight $* * *$ & 12 & 63.16 & 17 & 14.29 & 19 & 27.94 \\
Obese**** & - & - & 1 & 2.04 & 1 & 1.47 \\
\hline
\end{tabular}

Underweight $\left(\mathrm{BMI} \leq 18.5 \mathrm{~kg} / \mathrm{m}^{2}\right)$, ** Normal (BMI between $18.5-24.9$ $\mathrm{kg} / \mathrm{m}^{2}$ ), *** Overweight (BMI between $25-29.9 \mathrm{~kg} / \mathrm{m}^{2}$ ), $* * * *$ Obese (BMI $\geq$ $\left.30 \mathrm{~kg} / \mathrm{m}^{2}\right)$.

\subsection{Students' Eating Habits}

Frequency of food groups consumption was correlated with nourished status (Table 3). The majority of students with BMI $\leq 24.9 \mathrm{~kg} / \mathrm{m}^{2}(80.85 \%)$, and $42.11 \%$ of students with BMI $\geq 25 \mathrm{~kg} / \mathrm{m}^{2}$ reported taking fruits every day. The difference of frequency of fruit consumption was statistical significant (chi-squared test: $\mathrm{P}=0.0004)$. There were differences in consumption frequency of raw vegetables (chisquared test: $\mathrm{P}=0.046$ ) and coca cola and beverages (chisquared test: $\mathrm{P}=0.005$ ). Intake of raw vegetables was more common among students with $\mathrm{BMI} \leq 24.9 \mathrm{~kg} / \mathrm{m}^{2}$ than students with $\mathrm{BMI} \geq 25 \mathrm{~kg} / \mathrm{m}^{2}$ (43.48\% vs. $15.79 \%$ respectively). Among students with $\mathrm{BMI} \leq 24.9 \mathrm{~kg} / \mathrm{m}^{2}, 78.26 \%$ reported drinking coca cola and beverages monthly or never compared to $36.84 \%$ students with $\mathrm{BMI} \geq 25 \mathrm{~kg} / \mathrm{m}^{2}$. Consumption frequency of other food group had no differences regarding to nourish status. 
Table 3. Correlation between frequency of food groups consumption and nourish status.

\begin{tabular}{|c|c|c|c|c|c|c|}
\hline \multirow{2}{*}{ Food groups } & \multirow{2}{*}{ Frequency of consumption * } & \multicolumn{2}{|c|}{$\mathrm{BMI} \leq 24.9$} & \multicolumn{2}{|c|}{$\mathrm{BMI} \geq 25$} & \multirow[b]{2}{*}{$\mathbf{p}$} \\
\hline & & $\mathbf{N}$ & $\%$ & $\mathbf{N}$ & $\%$ & \\
\hline \multirow{3}{*}{ fruits } & daily & 38 & 80.85 & 8 & 42.11 & \multirow{3}{*}{0.004} \\
\hline & weekly & 8 & 17.02 & 10 & 52.63 & \\
\hline & monthly or never & 1 & 2.13 & 1 & 5.26 & \\
\hline \multirow{3}{*}{ raw vegetables } & daily & 20 & 43.48 & 3 & 15.79 & \multirow{3}{*}{0.046} \\
\hline & weekly & 22 & 47.83 & 13 & 68.42 & \\
\hline & monthly or never & 4 & 8.69 & 3 & 15.79 & \\
\hline \multirow[t]{2}{*}{ cooked vegetables } & weekly & 21 & 45.65 & 6 & 31.58 & \multirow[t]{2}{*}{0.631} \\
\hline & monthly or never & 9 & 19.57 & 6 & 31.58 & \\
\hline \multirow{3}{*}{ coca cola and beverages } & daily & 4 & 8.70 & 4 & 21.05 & \multirow{3}{*}{0.005} \\
\hline & weekly & 6 & 13.04 & 8 & 42.11 & \\
\hline & monthly or never & 36 & 78.26 & 7 & 36.84 & \\
\hline \multirow{3}{*}{$\begin{array}{l}\text { sweets (ice cream, } \\
\text { chocolate,...) }\end{array}$} & daily & 28 & 60.87 & 7 & 36.84 & \multirow{3}{*}{0.132} \\
\hline & weekly & 13 & 28.26 & 9 & 47.37 & \\
\hline & monthly or never & 5 & 10.87 & 3 & 15.79 & \\
\hline \multirow[t]{2}{*}{ cake } & weekly & 21 & 45.65 & 10 & 52.63 & \multirow[t]{2}{*}{0.949} \\
\hline & monthly or never & 14 & 30.44 & 5 & 26.32 & \\
\hline \multirow{3}{*}{ chips } & daily & 2 & 4.35 & - & - & \multirow{3}{*}{0.713} \\
\hline & weekly & 8 & 17.39 & 4 & 21.05 & \\
\hline & monthly or never & 36 & 78.26 & 15 & 78.95 & \\
\hline \multirow{3}{*}{ fried potatoes } & daily & 3 & 6.52 & - & - & \multirow{3}{*}{0.904} \\
\hline & weekly & 2 & 4.35 & 3 & 15.79 & \\
\hline & monthly or never & 41 & 89.13 & 16 & 84.21 & \\
\hline \multirow{3}{*}{$\begin{array}{l}\text { fast food (hamburger, hotdog, } \\
\text { sausages) }\end{array}$} & daily & - & - & 1 & 5.26 & \\
\hline & weekly & 5 & 10.87 & 4 & 21.05 & 0.069 \\
\hline & monthly or never & 41 & 89.13 & 14 & 73.69 & \\
\hline & daily & 38 & 80.85 & 14 & 73.68 & \\
\hline bread and derivatives & weekly & 7 & 14.89 & 3 & 15.79 & 0.386 \\
\hline & monthly or never & 2 & 4.26 & 2 & 10.53 & \\
\hline & daily & 31 & 68.89 & 14 & 73.68 & \\
\hline & daily & 34 & 73.92 & 12 & 63.16 & \\
\hline coffee & weekly & 6 & 13.04 & 3 & 15.79 & 0.359 \\
\hline & monthly or never & 6 & 13.04 & 4 & 21.05 & \\
\hline & daily & 9 & 20.00 & 5 & 26.32 & \\
\hline red meat & weekly & 25 & 55.56 & 9 & 47.36 & 0.814 \\
\hline & monthly or never & 11 & 24.44 & 5 & 26.32 & \\
\hline & daily & 12 & 26.67 & 7 & 36.84 & \\
\hline white meat & weekly & 25 & 55.56 & 9 & 47.37 & 0.512 \\
\hline & monthly or never & 8 & 17.78 & 3 & 15.79 & \\
\hline & daily & 3 & 6.67 & 2 & 10.53 & \\
\hline fish & weekly & 13 & 28.89 & 4 & 21.05 & 0.995 \\
\hline & monthly or never & 29 & 64.44 & 13 & 68.42 & \\
\hline
\end{tabular}

* For some food items a few participants did not indicates consumption frequency.

Between gender there were significant differences in consumption frequencies of cooked vegetables (MannWhitney test: $\mathrm{P}=0.003$ ), coca cola and beverages (MannWhitney test: $\mathrm{P}=0.011$ ), sweets (ice cream, chocolate...) (Mann-Whitney test: $\mathrm{P}=0.03$ ), fast food (hamburger, hotdog, sausages) (Mann-Whitney test: $\mathrm{P}=0.001$ ). Only consumption frequencies of coca cola and beverages is statistical associated with nourish status in male $(\chi=4.099$; $\mathrm{P}=0.049$ ).

\section{Discussion}

Mean BMI for male was $25.12 \pm 3.02 \mathrm{~kg} / \mathrm{m}^{2}$ and for female $22.00 \pm 2.81 \mathrm{~kg} / \mathrm{m}^{2}$. There are some differences in anthropometric measures of students in sample of this study and anthropometric reference data for adults in general population: BMI for male $28.6 \mathrm{~kg} / \mathrm{m}^{2}$ and for male 28.7 $\mathrm{kg} / \mathrm{m}^{2}$. [7]

The prevalence of overweight was more common among male students compared to females $(63.16 \%$ vs. $14.29 \%)$. Significant difference in nourish status between genders is common in student population. [8] Intakes of fruit and raw vegetables were more common among students with BMI $\leq 24.9 \mathrm{~kg} / \mathrm{m}^{2}$ than students with $\mathrm{BMI} \geq 25 \mathrm{~kg} / \mathrm{m}^{2}(\chi=9.644$; $\mathrm{P}=0.0004$ and $\chi=4.601 ; \mathrm{P}=0.046$ respectively), whereas consumption frequency of coca cola and beverages was less common $(\chi=10.428 ; \mathrm{P}=0.005)$. There are conflicting results of randomized controlled trials on the effects of increased fruit 
and vegetable consumption on changes in body weight. [9] Consumption frequencies of coca cola and beverages is statistical associated with nourish status in male $(\chi=4.099$; $\mathrm{P}=0.049)$. Over the past several decades, as obesity rates increased sharply, consumption of added sugars in beverages is increased that coursed controversial scientific debate. [10]

\section{Conclusion}

The findings of this study are limited by the choose of a student's sample. Nevertheless, the present study gives baseline information about weight status and eating habits among a sample of university students. Regulating the energy density of food could be used as an approach for successful body weight control.

\section{Conflict of Interests}

The authors declare that they have no competing interests.

\section{References}

[1] WHO: Diet, nutrition and the prevention of chronic diseases. Technical Report Series No. 916, WHO Geneva, 2003.

[2] Nihtila A, West N, Lussi A, Bouchard P, Ottolenghi L, Senekola E, et all. Oral Health Behavior and Lifestyle Factors among Overweight and Non-Overweight Young Adults in Europe: A Cross-Sectional Questionnaire Study. Healthcare (Basel). 2016; 4 (2): 21.
[3] Arria AM, Caldeira KM, Bugbee BA, Vincent KB, O'Grady KE. Trajectories of energy drink consumption and subsequent drug use during young adulthood. Drug Alcohol Depend. 2017; 179: 424-32.

[4] WHO Global Health Observatory Data Repository [online database]. Geneva, World Health Organization (http:// http://www.who.int/gho/en/, accessed 21 October 2017).

[5] World Medical Association Declaration of Helsinki. Ethical Principles for Medical Research Involving Human Subjects, 2008.

[6] Center for Disease Control. Global School Based Student Health Survey, 2010.

[7] Fryar CD, Gu Q, Ogden CL. Anthropometric reference data for children and adults: United States, 2007-2010. National Center for Health Statistics. Vital Health Stat 11 (252). 2012.

[8] Salameh P, Jomaa L, Issa C, Farhat G, Salamé J, Zeidan N, Baldi I. Assessment of dietary intake patterns and their correlates among university students in Lebanon. Front Public Health 2014; 2: 185.

[9] Schwingshackl L, Hoffmann G, Kalle-Uhlmann T, Arregui M, Buijsse B, Boeing H. Fruit and Vegetable Consumption and Changes in Anthropometric Variables in Adult Populations: A Systematic Review and Meta-Analysis of Prospective Cohort Studies. PLoS One. 2015 Oct 16; 10 (10): e0140846.

[10] Massougbodji J, Le Bodo Y, Fratu R, De Wals P. Reviews examining sugar-sweetened beverages and body weight: correlates of their quality and conclusions. Am J Clin Nutr May 1, 2014 99: 1096-104. 